\title{
植生がガリ形成に及ぼす効果 EFFECTS OF VEGETATION ON GULLY FORMATION
}

\author{
山口 里実 ${ }^{1} \cdot$ 泉 典洋 ${ }^{2}$ \\ Satomi Yamaguchi and Norihiro Izumi \\ 1 学生会員 東北大学大学院工学研究科土木工学専攻（980-8579 宮城県仙台市青葉区青葉 06） \\ ${ }^{2}$ 正会員 Ph.D. 東北大学助教授 大学院工学研究科土木工学専攻 (同上)
}

\begin{abstract}
Surface erosion is increasingly caused by forest clearance for cultivation and urbanization. It is commonly observed that gullies formed at the edge of plateau surfaces tremendously accelerate surface erosion. It is accordingly important to study the mechanism of gully formation and the effects of vegetation in order to reduce soil erosion. This paper presents a mathematical model as to how vegetation effects on gully formation in terms of a linear stability analysis. It is suggested that vegetation decelerates gully development by reducing gully spacing and flow intensification. It is found that a slight increase of critical shear stress due to vegetation prevents gully formation effectively.
\end{abstract}

Key Words : soil erosion, gully formation, vegetation, linear stability analysis

\section{1. はじめに}

大地の表面は雨水によって発生する表面流によっ て永続的な侵食を受けている. 農地や都市の開発に 伴う森林伐採は, この地表面の侵食を著しく増加さ せる. 侵食によって肥沃な土壌が洗い流されると, やがてその土地はやせてしまう。このような土袞侵 食は農業生産性を低下させ, 有史以来, 人類の生活 に深刻な影響を与えてきた. 古代ギリシャの崩壊も 土猿侵食による農業生産性が低下したことに原因が あるといわれている。耕作地や都市化が益々広がり つつある近年において, 土壤侵食がもたらす問題は, さらに深刻なものとなり，その影響は様々な分野に 及んでいる. 例えば河川や湖沼や海洋においては, 侵食されて流入してくる土壤によって，その生態系 は深刻な影響を受けている.

図-1 は中国黄土高原の写真である.ここでは長い 年月にわたる森林伐採によって土壤侵食が進み, 中 国内でも最も農業生産性の低い土地となっている ${ }^{1)}$. 図に見られるように地表には多くのガリが形成され, 土壤侵食を著しく増大させている. 図-2 は沖縄読谷 村付近に位置する段々畑の斜面の様子である.この 地域では, 畑地の開発による森林伐採によって激し

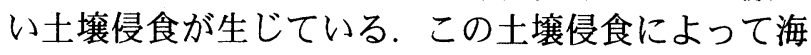
に流入した赤土は, 海中の生物環境を悪化させ, 珊 瑚に壊滅的な打撃を与えている. 畑地面の縁には, 2 30m 間隔で図-2a に示したような黄土高原のもの に類似のガリが形成されている。このようなガリが

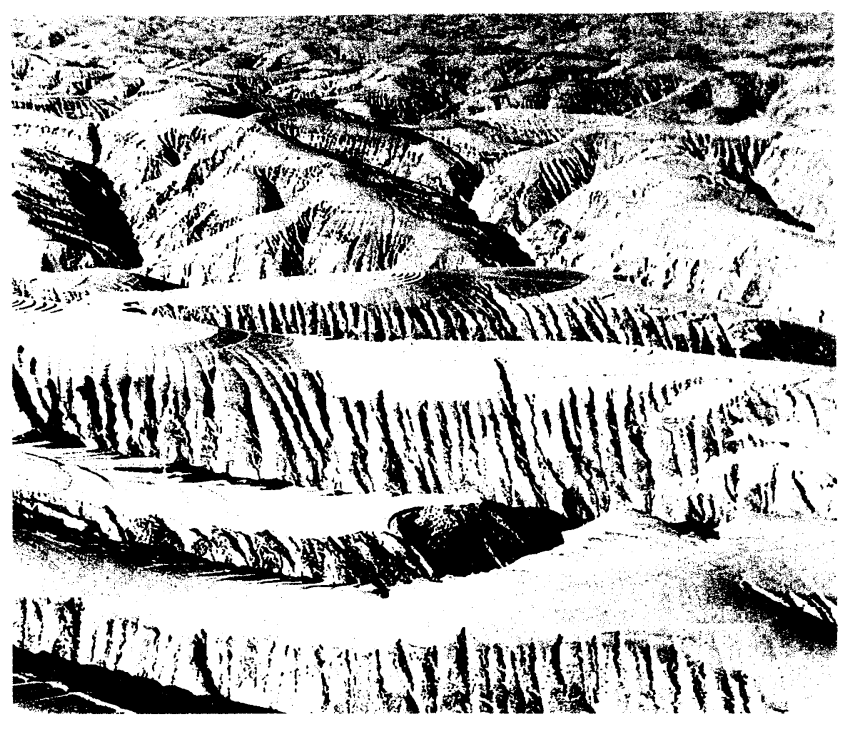

図-1 黄土高原(図は芦田和男氏の好意により提供を受けた)

一旦形成されると，流れと侵食の集中によって，侵 食量が飛躍的に増大することが知られている(図-2b). したがって土壌侵食を効率的に減少させるためには, ガリの形成メカニズムとそれに対する植生の効果を 明らかにすることが必要不可欠となる.

\section{2. 斜面下流端から発生する水路群}

下流端に段差が存在する斜面では，段差による流 速の加速によって底面剪断力が増大し, 段差近傍で 


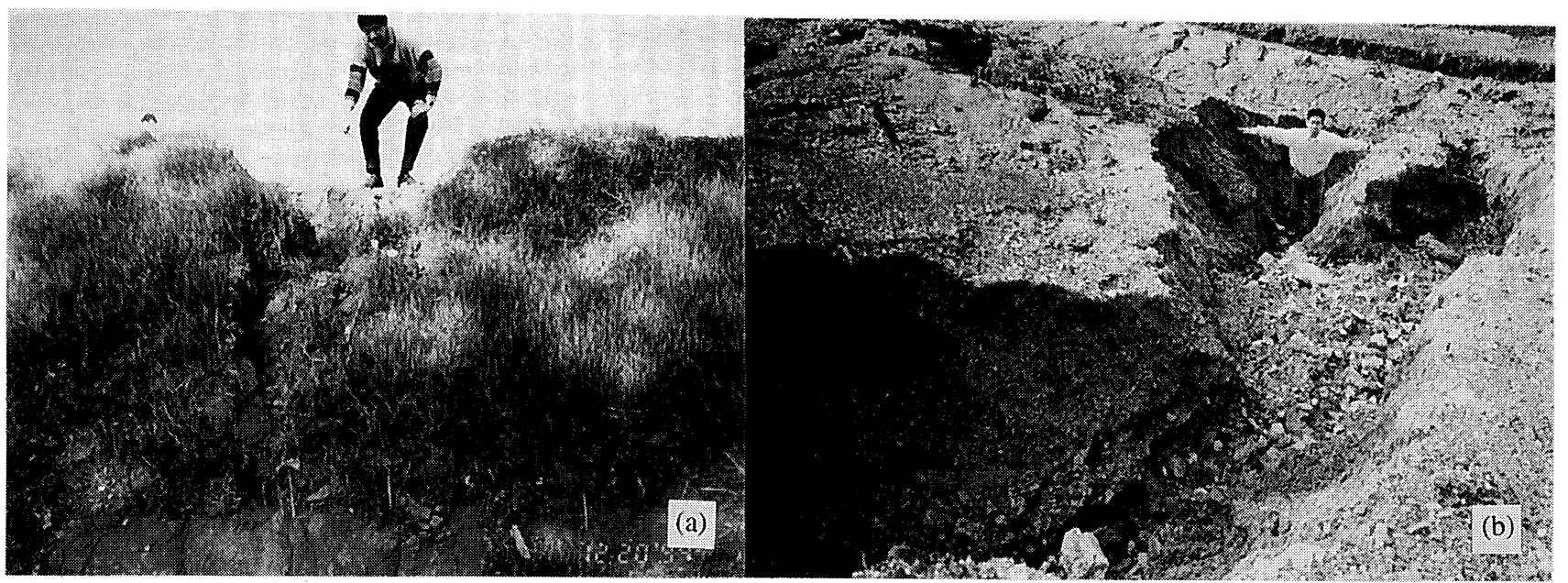

図-2 (a) 段段畑の斜面上に見られるガリ. (b) 発達したガリによって侵食が進んだ斜面下流側. 沖縄読谷村付近.

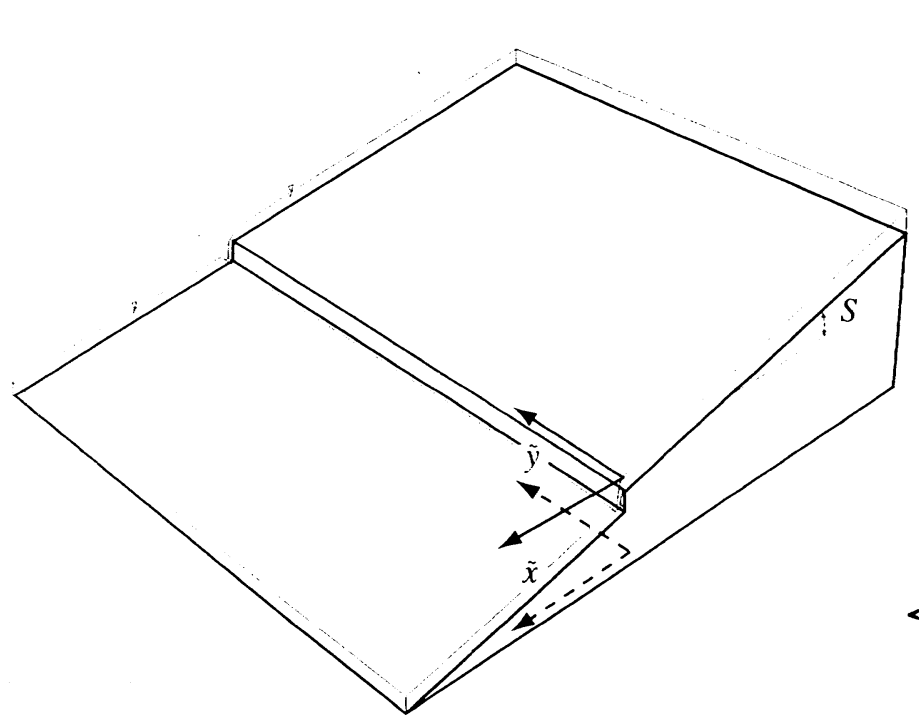

(a)下流端に段差を有する斜面

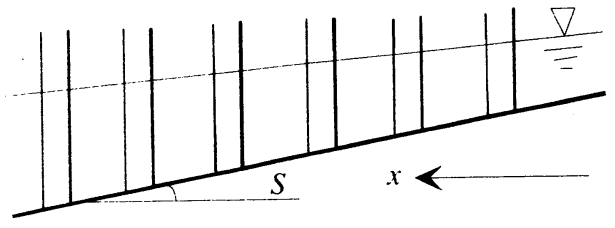

(b) 斜面上に存在する植生

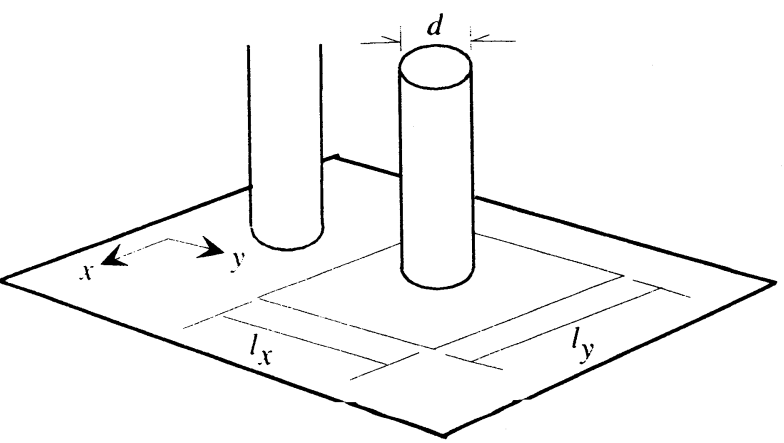

(c) 植生密度

図-3 モデルの概念図と座標系.

侵食が発生する.この侵食によって，段差はある一 定の形状を維持して上流側に前進していくことにな る. 泉 ${ }^{21}$ はこのような段差に対してサイン型の微少擾 乱を与え, 発達率と波数の関係を調べるという線形 安定解析の手法によって, 水路群の形成される初期 間隔を予測している，その結果によれば，斜面下流 端から発生する水路群の初期形成間隔は限界水深の 1000 倍程度の間隔になることがわかっている.

本研究では, 植生を考慮した浅水流方程式を用い た線形安定解析を行うことによって, 斜面下流端か ら発生する水路群(ガリ)の初期形成過程に植生がど のような影響をもたらすのかを明らかにする.

\section{3. 植生を有する斜面}

図-3a に示すような, 下流端に段差を有する一様勾 配 $S$ の斜面を考える. 図のように水平面内に $\tilde{x}$ およ

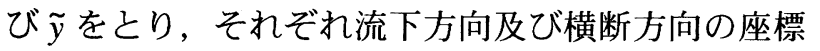
とする. 降雨によって発生する斜面上の表面流は下 流方向に増加することになるが，ここで考えている ように斜面長に比べて十分短い区間を対象とする場 合降雨による流量の変化は無視できることがわかっ ている. ここでも流下方向に流量一定と仮定する ${ }^{3)}$.

このような下流端に段差を有する斜面上に, 図-3b, cに示したような植生が存在する場合を考える. 植生 は斜面上に一様に存在しているとする. 
いま斜面の勾配が十分小さく段差より上流の斜面 上のいたる所で流れは常流となっていると仮定する. 段差付近では活発な侵食が生じるため, 段差は上流 側へ前進していく. 段差や流れが横断方向に完全に 一様であれば段差は横断方向に一直線のまま上流側 に移動することになるが実際は流れと侵食の集中が ある間隔で発生し, ガリが発生することになる。次 節以降ではこのように侵食によって上流側に前進す る段差に対してサイン型の微小擾乱を与え, その発 達率を調べる。いわゆる線形安定解析の手法を用い て擾乱の発達速度を波数の関数として求め, 卓越波 数を導く.

\section{4. 定式化}

\section{(1) 支配方程式}

斜面上の流れの運動の支配方程式は次の浅水流方 程式及び連続の式となる。

$$
\begin{gathered}
\tilde{u} \frac{\partial \tilde{u}}{\partial \tilde{x}}+\tilde{v} \frac{\partial \tilde{u}}{\partial \tilde{y}}=-g \frac{\partial \tilde{h}}{\partial \tilde{x}}-g \frac{\partial \tilde{\eta}}{\partial \tilde{x}}-\frac{\tilde{\tau}_{x}}{\rho \tilde{h}}-\frac{D_{x}}{\rho \tilde{h}} \\
\tilde{u} \frac{\partial \tilde{v}}{\partial \tilde{x}}+\tilde{v} \frac{\partial \tilde{v}}{\partial \tilde{y}}=-g \frac{\partial \tilde{h}}{\partial \tilde{y}}-g \frac{\partial \tilde{\eta}}{\partial \tilde{y}}-\frac{\tilde{\tau}_{y}}{\rho \tilde{h}}-\frac{D_{y}}{\rho \tilde{h}} \\
\frac{\partial \tilde{u} \tilde{h}}{\partial \tilde{x}}+\frac{\partial \tilde{v} \tilde{h}}{\partial \tilde{y}}=0
\end{gathered}
$$

ここで $\tilde{x}$ および $\tilde{y}$ は図-3a に示したようにそれぞれ 流下方向及び横断方向の座標である. また $\tilde{u}$ 及び $\tilde{v}$ はそれぞれ $\tilde{x}$ 及び $\tilde{y}$ 方向の流速成分, $\tilde{h}$ 及び $\tilde{\eta}$ はそ れぞれ水深及び斜面高さである. また $\widetilde{\tau}_{x}$ 及び $\widetilde{\tau}_{y}$ はそ れぞれ底面剪断力の $\tilde{x}$ 及び $\tilde{y}$ 成分であり, 次式で表 される.

$$
\left(\tilde{\tau}_{x}, \tilde{\tau}_{y}\right)=\tilde{\tau}\left(\tilde{u}^{2}+\tilde{v}^{2}\right)^{-1 / 2}(\tilde{u}, \tilde{v}), \quad \tilde{\tau}=\rho C_{f}\left(\tilde{u}^{2}+\tilde{v}^{2}\right)
$$

ここで $C_{f}$ は抵抗係数であり, 簡単のため定数と見な す. また $D_{x}$ 及び $D_{y}$ はそれぞれ植生による抗力の $\tilde{x}$ 及び $\tilde{y}$ 方向成分であり, 次式で表されるとする.

$$
\left(D_{x}, D_{y}\right)=\frac{1}{2} \rho C_{D} A_{p} \tilde{h}\left(\tilde{u}^{2}+\tilde{v}^{2}\right)^{1 / 2}(\tilde{u}, \tilde{v})
$$

ここで $C_{D}$ は植生の抗力係数, $A_{p}$ は植生の密度を表 すパラメータで図-2c に示すように $d /\left(l_{x} l_{y}\right)$ と表され る.

本理論で対象としている主に粘性土で構成されて いるような斜面では, 斜面高さは侵食によって変化 し, その時間変化は侵食速度 $\tilde{E}$ を用いて次式で表さ れる ${ }^{3)}$.

$$
\frac{\partial \tilde{\eta}}{\partial \tilde{t}}=-\tilde{E}(\tilde{\tau}), \quad \tilde{E}(\tilde{\tau})= \begin{cases}0, & \tilde{\tau} \leq \tilde{\tau}_{t h}, \\ \alpha\left(\frac{\tilde{\tau}}{\tilde{\tau}_{t h}}-1\right)^{\gamma}, & \tilde{\tau} \geq \tilde{\tau}_{t h},\end{cases}
$$

\section{ここで $\tilde{\tau}_{t h}$ は限界底面剪断力である.}

斜面下流端の段差を落下する際, 斜面上で常流
だった流れは段差付近に存在するフルード限界点で 射流へと変化する. フルード限界点も段差とともに 上流側に前進するが，定常状態におけるフルード限 界点を $\tilde{x}$ の原点かつ $\tilde{\eta}$ の基準点とすると, 次の関係 が成り立っている.

$$
\frac{\tilde{u}}{(g \tilde{h})^{1 / 2}}=1, \quad \tilde{\eta}=0, \quad \text { at } \quad \tilde{t}=0, \quad \tilde{x}=0
$$

斜面より十分上流においては等流状態が実現して いる. 等流流速を $\tilde{u}_{n}$ と表すと次の関係が成り立って いる.

$$
\tilde{u}=\tilde{u}_{n} \quad \text { as } \quad \tilde{x}=-\infty
$$

\section{(2) 無次元化}

次の無次元化を導入する.

$$
\begin{gathered}
(\tilde{u}, \tilde{v})=U_{c}(u, v), \quad(\tilde{h}, \tilde{\eta})=D_{c}(h, \eta) \\
(\tilde{x}, \tilde{y})=\frac{D_{c}}{C_{f}}(x, y), \tilde{t}=D_{c}\left[\alpha\left(\frac{\tilde{\tau}_{c}}{\tilde{\tau}_{t h}}\right)^{\gamma}\right]^{-1} t \\
\tilde{\tau}_{c}=\rho C_{f} U_{c}^{2}, \tilde{k}=\frac{C_{f}}{D_{c}} k
\end{gathered}
$$

ここで $U_{c}$ 及び $D_{c}$ はそれぞれ限界流速及び限界水深 であり, 次式で表される.

$$
U_{c}=(q g)^{1 / 3}, \quad D_{c}=\left(q^{2} / g\right)^{1 / 3}
$$

ここで $q$ は段差近傍における単位幅当たりの流量で あり, 一定であると仮定している.

このとき式(1)-(4)は次式のように表される.

$$
\begin{aligned}
u \frac{\partial u}{\partial x}+v \frac{\partial u}{\partial y}= & -\frac{\partial h}{\partial x}-\frac{\partial \eta}{\partial x}-\frac{\left(u^{2}+v^{2}\right)^{1 / 2} u}{h} \\
& -\chi\left(u^{2}+v^{2}\right)^{1 / 2} u \\
u \frac{\partial v}{\partial x}+v \frac{\partial v}{\partial y}= & -\frac{\partial h}{\partial y}-\frac{\partial \eta}{\partial y}-\frac{\left(u^{2}+v^{2}\right)^{1 / 2} v}{h} \\
& -\chi\left(u^{2}+v^{2}\right)^{1 / 2} v \\
\frac{\partial u h}{\partial x} & +\frac{\partial v h}{\partial y}=0 \\
\frac{\partial \eta}{\partial t}= & -E\left(u^{2}+v^{2}\right)
\end{aligned}
$$

ここで $\chi は$ 無次元化された植生密度であり, 次式で 表される.

$$
\chi=C_{D} A_{p} D_{c} / 2 C_{f}
$$

また $E$ は無次元化された侵食速度であり, 次式で表 される。

$$
E\left(u^{2}+v^{2}\right)= \begin{cases}\left(u^{2}+v^{2}-\theta\right)^{\gamma}, & u^{2}+v^{2} \geq \theta \\ 0, & u^{2}+v^{2} \leq \theta\end{cases}
$$

ここで $\theta$ は無次元化された限界剪断力であり, 次式 で表される.

$$
\theta=\frac{\tilde{\tau}_{t h}}{\tilde{\tau}_{c}}
$$

式(7)及び(8)を無次元化すると次式が得られる. 


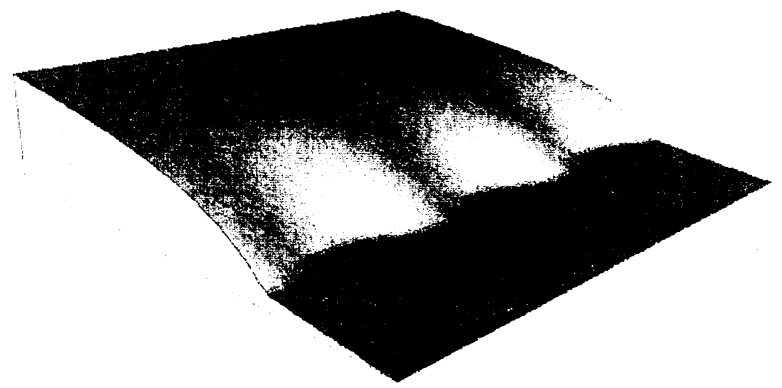

図-4 段差近傍に与えられた 3 次元的な擾乱の概念図

$$
\begin{gathered}
u^{2}=h, \quad \eta=0 \text { at } x=0 \\
u=u_{n}, \quad \text { as } x \rightarrow-\infty
\end{gathered}
$$

\section{(3) 座標变換}

次のような座標変換を導入する.

$$
t^{*}=t, \quad x^{*}=x+c t, \quad \eta^{*}=\eta-\left[c \sigma-E\left(u_{n}^{2}\right)\right] t
$$

ここで $\sigma$ は正規化された斜面勾配であり，常流を仮 定している現在のケースでは 1 より小さい. 上記の 座標変換は $x$ 方向に $-c$ で移動し, 鉛直方向に $c \sigma-E\left(u_{n}^{2}\right)$ で移動する座標系で見ていることに相当 していて，見かけ上斜面の形状が時間的に変化しな いような座標系をとっている。.このような座標変換 を用いて(11)-(14)式は次のように書き換えられる.

$$
\begin{gathered}
u \frac{\partial u}{\partial x}+v \frac{\partial u}{\partial y}=-\frac{\partial h}{\partial x}-\frac{\partial \eta}{\partial x}-\frac{\left(u^{2}+v^{2}\right)^{1 / 2} u}{h} \\
-\chi\left(u^{2}+v^{2}\right)^{1 / 2} u \\
u \frac{\partial v}{\partial x}+v \frac{\partial v}{\partial y}=-\frac{\partial h}{\partial y}-\frac{\partial \eta}{\partial y}-\frac{\left(u^{2}+v^{2}\right)^{1 / 2} v}{h} \\
-\chi\left(u^{2}+v^{2}\right)^{1 / 2} v \\
\frac{\partial u h}{\partial x}+\frac{\partial v h}{\partial y}=0 \\
\frac{\partial \eta}{\partial t}+c \frac{\partial \eta}{\partial x}+c \sigma+E\left(u^{2}+v^{2}\right)-E\left(u_{n}^{2}\right)=0
\end{gathered}
$$

上式では表記を簡単にするため*を落としている.

\section{5. 基本定常解}

まず定常解を求める. 式(21)-(24)において y 方向へ の変化と $v$ 及び時間変化を表す項を無視すると次式 が得られる。

$$
\begin{gathered}
u \frac{\partial u}{\partial x}=-\frac{\partial h}{\partial x}-\frac{\partial \eta}{\partial x}-\frac{u^{2}}{h}-\chi u^{2} \\
\frac{\partial u h}{\partial x}=0 \\
c \frac{\partial \eta}{\partial x}+c \sigma+E\left(u^{2}\right)-E\left(u_{n}^{2}\right)=0
\end{gathered}
$$

上式から容易に次式を導くことができる.

$$
\frac{d \eta}{d x}=-\sigma-c^{-1}\left[E\left(u^{2}\right)-E\left(u_{n}^{2}\right)\right]
$$

$$
\frac{d u}{d x}=\frac{u^{5}+\chi u^{4}+u^{2} d \eta / d x}{1-u^{3}}
$$

原点 $(x=0)$ では定義により $u=1$ である. 式(29)が原点 において特異性を持たないという条件のもとで，定 常な斜面形状の前進速度 $c$ は次式のように求められ る.

$$
c=\frac{E(1)-E\left(u_{n}^{2}\right)}{1+\chi-\sigma}
$$

$x \rightarrow-\infty$ は等流状態が維持されており, $d u / d x=0$ となっていることから式(28)及び(29)より次 の関係が導かれる。

$$
\chi u_{n}^{2}+u_{n}^{3}-\sigma=0
$$

式(28), (29)及び(30)と式(31)の解として求められる $u_{n}$ 用いれば, 定常状態の流速分布は次のように導か れる。

$$
\int_{1}^{u} \frac{1-u^{3}}{\chi u^{4}+u^{5}-\sigma u^{2}-(1-\sigma) \frac{E\left(u^{2}\right)-E\left(u_{n}^{2}\right)}{E(1)-E\left(u_{n}^{2}\right)} u^{2}} d u=x
$$

更に上式から得られた流速分布を用いて式(28)を積 分することによって一定の形状を維持しながら上流 側へ前進していく斜面形状が導かれる.

\section{6. 線形安定解析}

前節で求めた定常解に対して斜面横断方向に次の ような波状の微小擾乱を与える.

$$
\eta=a \cos k y \quad \text { at } t=0, \quad x=0
$$

その概念図を図-4 に示す.このような擾乱が与えら れた場合，各変数は次のように表される.

$$
\begin{gathered}
u=u_{0}(x)+a e^{\omega t} u_{1}(x) \cos k y+\cdots, \\
v=a e^{\omega t} v_{1}(x) \sin k y+\cdots, \\
h=h_{0}(x)+a e^{\omega t} h_{1}(x) \cos k y+\cdots \\
\eta=\eta_{0}(x)+a e^{\omega t} \eta_{1}(x) \cos k y+\cdots
\end{gathered}
$$

ここで $u_{0}, h_{0}$ 及び $\eta_{0}$ は前節ですでに求めた定常解で ある. $\omega$ は擾乱の発達初期における発達速度を表し ている.

式(34)を式(21)-(24)に代入して, $a$ の一次の項だけ を残し整理すると次の方程式系が得られる.

$$
\begin{gathered}
\frac{\partial u_{1}}{\partial x}=\frac{\left(u_{0}^{2}+u_{0}^{-1}\right) u_{0}^{\prime}+2\left(u_{0}+\chi\right) u_{0}^{3}-c^{-1} E_{u}\left(u_{0}^{2}\right) u_{0}^{2}}{1-u_{0}^{3}} u_{1} \\
\quad-\frac{k}{1-u_{0}^{3}} v_{1}-\frac{u_{0} u_{0}^{\prime}+u_{0}^{6}}{1-u_{0}^{3}} h_{1}-\frac{c^{-1} \omega u_{0}^{2}}{1-u_{0}^{3}} \eta_{1} \\
\frac{\partial v_{1}}{\partial x}=-\left(u_{0}+\chi\right) v_{1}+\frac{k}{u_{0}} h_{1}+\frac{k}{u_{0}} \eta_{1} \\
\frac{\partial h_{1}}{\partial x}=-\frac{2 u_{0}^{\prime}+2\left(u_{0}+\chi\right) u_{0}-c^{-1} E_{u}\left(u_{0}^{2}\right)}{1-u_{0}^{3}} u_{1} \\
+\frac{k u_{0}}{1-u_{0}^{3}} v_{1}-\frac{u_{0}^{4}+u_{0}^{2} u_{0}^{\prime}}{1-u_{0}^{3}} h_{1}+\frac{c^{-1} \omega}{1-u_{0}^{3}} \eta_{1}
\end{gathered}
$$




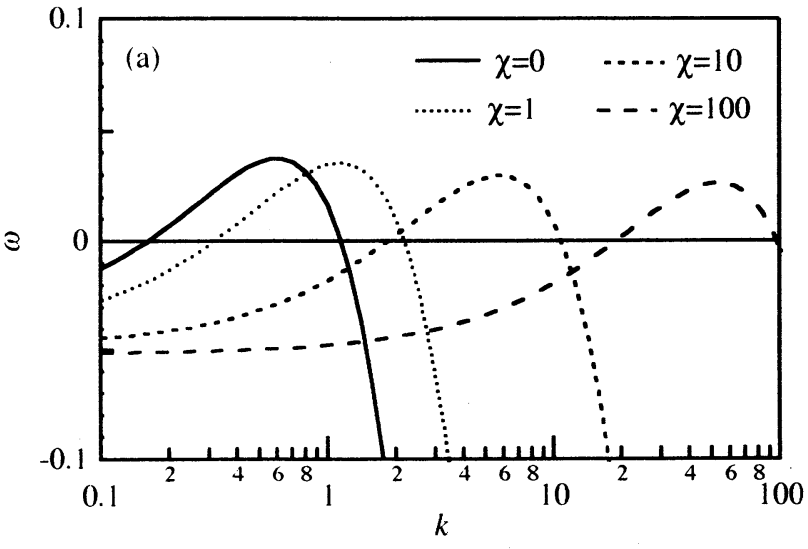

図-5 無次元波数 $k$ 及び無次元植生密度 $\chi$ による増幅率 $\omega$ の変化

$$
\frac{\partial \eta_{1}}{\partial x}=c^{-1} E_{u}\left(u_{0}^{2}\right) u_{1}-c^{-1} \omega \eta_{1}
$$

ここでプライムは $x$ による一回微分であり,$E_{u}$ は $u$ による一回微分を表わしている.

段差の上流無限溒点 $(x \rightarrow-\infty)$ では流れは等流状 態へと漸近し斜面下流端に与えられた擾乱の影響は 消失するため, 境界条件として次式が成り立つ.

$u_{1}=0, \quad v_{1}=0, \quad h_{1}=0, \quad \eta_{1}=0 \quad$ as $x \rightarrow-\infty$ (39) ただし上式においてはいずれか 3 個の条件が満たさ れれば他の 1 個も自動的に満たされるため, 実際は 3 個の境界条件が存在している. そこで, 式(33)からも う一つの境界条件として次式が導かれる.

$$
\eta_{1}=1 \text { at } x=0
$$

正則条件は式(35)及び(37)において原点 $x=0$ で特異 性を持たないという条件によって次のように導かれ る.

$$
\begin{gathered}
{\left[E_{u}(1)-2 c(p+\chi+1)\right]_{1}+k c v_{1}+c(p+1) h_{1}} \\
+\omega=0 \quad \text { at } \quad x=0
\end{gathered}
$$

式(35)-(38)は, $\omega$ に関する固有値問題であり, $x=0$ 及び $x \rightarrow-\infty に お り$ 点境界值問題に帰着できる. 式(35)-(38)は変数係数の微分方程式系であり, 解析的 に解くことができないため, ここでは数值的解法で ある緩和法を用いて解を求める.

\section{7. 結果および考察}

\section{（1）ガリの発達速度と卓越波数}

図-5 に正規化した限界剪断力 $\theta$, 波数 $k$ 及び無次 元植生密度 $\chi$ による擾乱の発達率 $\omega$ の変化を示す. ここで正規化した斜面勾配 $\sigma$ は 0 , 侵食関数のべき数 rは 2.0 を用いている. $\omega$ が正ならば擾乱は発達し, 負ならば減衰する。 $\omega$ が正で, さらに $\omega$ を最大とす る $k$ が存在すればそれが無次元卓越波数 $k_{c}$ である.

図-5a は $\theta=0.5, \mathrm{~b}$ は $\theta=0.9$ に対応している. 図に よれば $\theta$ が大きくなるにつれて $\omega$ は小さくなること がわかる. $\theta$ が大きくなることは限界剪断力 $\widetilde{\tau}_{t h}$ に対 してフルード限界点での剪断力 $\tilde{\tau}_{c}$ が小さいことを意 味しており, 侵食されにくい表面では煎断力が限界 值を上回っていても, ガリが発生しないことを表わ

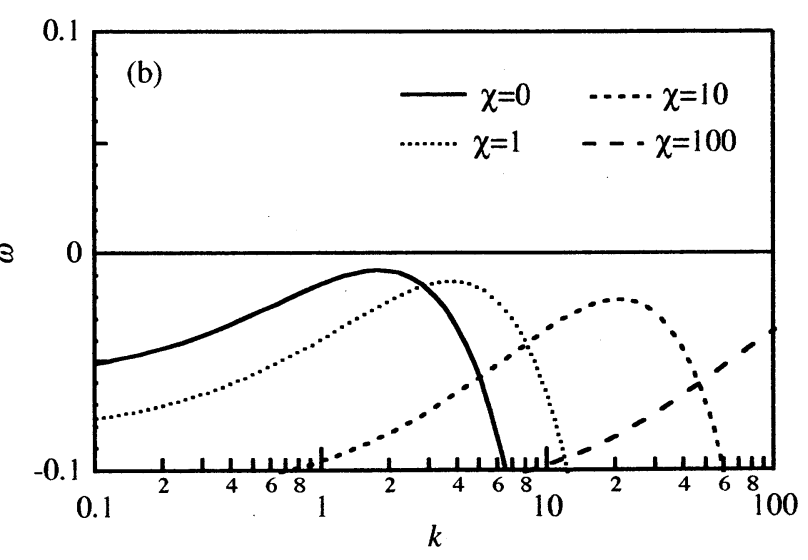

(a) $\gamma=2.0, \sigma=0, \theta=0.5$. (b) $\gamma=2.0, \sigma=0, \theta=0.9$.

している.

また a のケースをみると $\omega$ が正となる $k$ の範囲も $k_{c}$ も $\chi$ の值が大きいほど大きくなるという傾向が見 られる. 植生のない状態では $k_{c}=0.7$ 程度であるが, 植生密度 $\chi=1$ でほぼ 2 倍の $k_{c}=1.5, \chi=10$ でほぼ 10 倍の $k_{c}=7$ 程度となる. 卓越波長 $\tilde{\lambda}_{c}$ は $k_{c}$ を用いて 次のように表されるから

$$
\tilde{\lambda}_{c}=2 \pi \frac{D_{c} / C_{f}}{k_{c}}
$$

植生密度が大きくなると卓越波長が短くなり，支配 的なガリ間隔も小さくなることがわかる. また，ガ リの発生速度 $\omega に$ に, 予想に反して植生による大き な変化が見られないことがわかる.

\section{（2）計算例}

ここで得られた結果の意味をはっきりさせるため, 具体的な例を考えてみよう. 今, $200 \mathrm{~mm} / \mathrm{h}$ の雨が, 長さ $500 \mathrm{~m}$ の平坦な $(S=0$ の)畑地面に降ったとする. その時, 畑地面の縁から斜面に流入する雨水の単位 幅流量は $0.028 \mathrm{~m}^{2} / \mathrm{s}$ である. このとき, $U_{c}=0.65 \mathrm{~m} / \mathrm{s}$, $\mathrm{D}_{c}=0.043 \mathrm{~m}$, 限界剪断力については様々な研究結 果があり, 限界摩擦速度 $u_{t h}^{*}$ で $0.02 \mathrm{~m} / \mathrm{s}$ から $0.2 \mathrm{~m} / \mathrm{s}$ 程度の值であるといわれている ${ }^{4), 5)}$.ここでは比較的 侵食されやすい土猿を考えて $u_{t h}^{*}=0.04 \mathrm{~m} / \mathrm{s}$ とする. $C_{f}$ を 0.015 とすると, $\theta=0.5$ となる. 植生が存在し ない $(\chi=0)$ とすれば, 図-5a より卓越波数 $k_{c}=0.7$ 程 度となり, 式(42)より卓越波長 $\tilde{\lambda}_{c}$ すなわちガリの形 成間隔は $24.7 \mathrm{~m}$ となる．これは図-2に見られたガリ の間隔とオーダー的に一致している.

植生が樹木だけである場合, $A_{p}$ の值は $0.04 \mathrm{~m}^{-1}$ 程度 の值をとることが知られているが ${ }^{6}$, 茂みややぶなど が存在する場合はもっと大きな值をとり得る。ここ では $1 \mathrm{~m}^{2}$ 当りに太さ $1 \mathrm{~cm}$ の円柱様の植物茎が 160 本 存在している場合を想定して $A_{p}$ は $1 \mathrm{~m}^{-1}$ を仮定する. $C_{D}=2$ を用いると $\chi$ の值はおよそ 10 となる. このと き図-5a より $k_{c}=7$ 程度となり, 式(42)より $\tilde{\lambda}_{c}=2.47 \mathrm{~m}$ となる. 


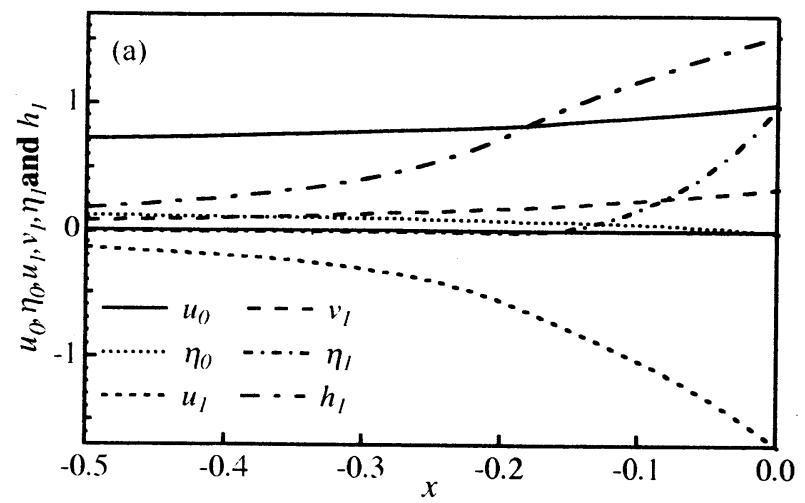

图-6 $u_{0}, \eta_{0}, u_{1}, v_{1}, h_{1}$ 及び $\eta_{1}$ の分布.

(b) $\gamma=1.5, \quad \sigma=0.1, \quad \theta=0.6, k=5.6, \quad \omega=0.03$.

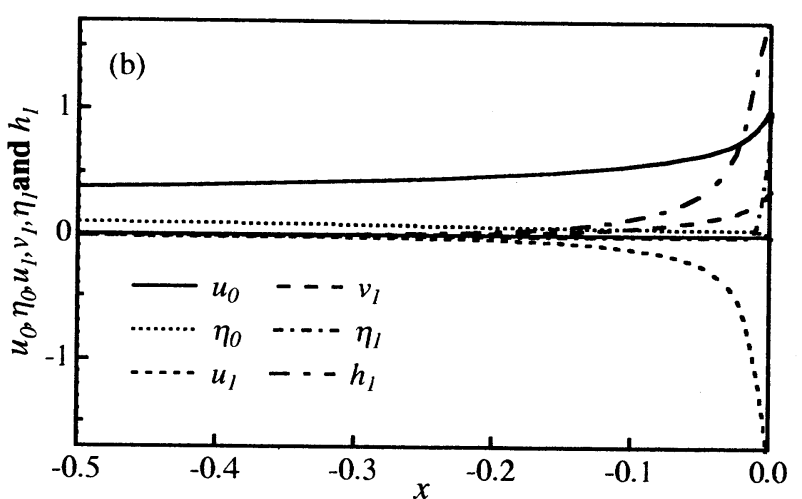

(a) $\gamma=1.5, \quad \sigma=0.1, \quad \theta=0.6, \quad k=0.5, \quad \omega=0.04$.

\section{(3) 植生によるガリ形成間隔の隇少}

図-6に $\gamma=1.5, \sigma=0.1, \theta=0.6$ のときの $u_{0}, \eta_{0}$, $u_{1} *, v_{1} *, h_{1}$ *及び $\eta_{1} *$ の分布を示す. a とbはそれぞ れ, 植生を考慮しない場合 $(\chi=0)$ と植生を考慮した場 合 $(\chi=10)$ を示している. いずれの場合も増幅率最大 の場合に対応している. 植生の存在する場合の方が すべての変数の変化が原点付近に限定されているこ とがわかる. 植生は粗度として働くため, 植生が存 在する斜面では背水の影響は原点付近のより狭い範 囲に限定される。したがって段差の影響も原点付近 の狭い領域に限定され，ガリが上流側の水を集める 影響も狭い領域に限定されてしまう。このことがガ リの間隔を狭くしている原因であると考えられる.

ガリの形成間隔が小さくなるということは，それ ぞれのガリに集まる流量が小さくなることを意味し ている. 前述したように初期形成時におけるガリの 発達速度は植生の存在によって大きな影響を受けな いが，それぞれのガリに集まる流量が小さくなるこ とはガリ発生後の発達速度を大きく減少させるもの と予想される.ただしその過程は非常に非線型性の 強いものであって，ここで行ったような線形理論で は説明できない. 今後の課題である.

\section{（4）植生による限界然断力増大の影䈏}

前項までは植生の存在下でも限界剪断力は変化し ないことを仮定したが，植生が存在する場合その根 による結合力などの効果のために限界剪断力が大き くなることが知られている ${ }^{7)}$.このとき $\theta$ が増加する ことになる. 例えば前項の計算例で植生の存在に よって $u_{t h}^{*}$ が $0.07 \mathrm{~m} / \mathrm{s}$ 程度まで増加したとする. その とき図-5bによれば $\omega$ は負となり, もはやガリは形成 されないことがわかる。

\section{8. 結論}

本論文では水路群形成の線形安定論に, 植生によっ
て流れが受ける抗力の影響を加味することによって， ガリの形成過程に対する植生の効果を明らかにした. それによって得られた知見を次に述べる.

a) 植生は, ガリの発生する波長領域および卓越波長 を小さくする．このことは植生によってガリの形 成間隔が小さくなることを意味している.

b) 植生は発生初期におけるガリの成長速度を小さく する効果は小さいが，ガリの形成間隔を小さくす ることによって，それぞれのガリが集める流量を 小さくし, その後の発達を抑える効果を有すると 考えられる。

c) 植生が限界剪断力を増大させる働きによって, 剪 断力が限界剪断力を上回っていてもガリは形成さ れにくくなる。

期辞 : 本論文の作成にあたり芦田和男氏には黄土高原の写 真の使用を快諾して頂いた：ここに記して，謝意を表する.

\section{觉考文献}

1) 黄河水利委員会治黄研究組 : 黄河の治水と開発（芦田 和男監修，馮金亭・匡尚富訳），古今書院，1989.

2) 泉 典洋 : 水路群形成の線形安定論一斜面下流端から の発生理論一，土木学会論文集，投稿中.

3) 泉 典洋 : 斜面下流端から発生する水路群について, 土木学会論文集, No. 521, pp. 79-91, 1995.

4) Raudkivi, A. J.: Loose Boundary Hydraulics. $2^{\text {nd }}$ Ed, Pergamon, 1976.

5) Dietrich, W. E., Wilson, C. J., Montgomery, E. R. and McLean, J.: Analysis of erosion thresholds, channel networks, and landscape morphology using a digital terain model, J. Geol., 101, pp. 259-278, 1993.

6) 泉 典洋, 池田駿介 : 側岸に樹木を有する直線喽床河 川の安定河床形状, 土木学会論文集, No. 411, pp. 151$160,1989$.

7) 福岡捷二, 渡辺和足, 柿沼孝治 : 堤防芝の流水に対す る侵食抵抗, 土木学会論文集, No. 491/ II -27, pp. 31-40, 1994.5.

(1998. 9. 30 受付) 